\title{
Interventional Stroke Management in a Patient With COVID-19
}

Kevin Yeboah, MD, Randal Edgell, MD, Joseph Conway, BS, and Amer Alshekhlee, MD, MSc

Neurology: Clinical Practice April 2021 vol. 11 no. 2 e199-e201 doi:10.1212/CPJ.0000000000000884

\author{
Correspondence \\ Dr. Alshekhlee \\ amer.alshekhlee@ \\ ssmhealth.com
}

There are now over a million cases of coronavirus disease 2019 (COVID-19) worldwide with thousands of reported deaths. ${ }^{1}$ Based on anecdotal evidence, ${ }^{2}$ it has been hypothesized that patients with COVID-19 are at risk of thromboembolism, causing acute coronary syndromes and ischemic stroke. Acute treatment outside the designated quarantine units poses a threat of spreading the illness to healthcare workers. We report a patient with severe acute respiratory syndrome due to corona virus infection (SARS-CoV-2) who developed acute ischemic stroke during the hospital course treated with mechanical thrombectomy. We emphasize the importance of adhering to institutional protocols to protect healthcare workers during the interventional management of acute stroke.

\section{Case}

A known diabetic and hypertensive 49-year-old woman presented with progressive shortness of breath, fever, and fatigue. She had mild respiratory distress requiring oxygen supplementation, was treated in an isolation unit for patients with COVID-19, and received therapy with hydroxychloroquine and azithromycin. She had elevated C-reactive protein (18.7; reference less than $0.5 \mathrm{mg}$ per $\mathrm{dL}$ ), lactate dehydrogenase (386; reference range $125-22$ units per $L)$, procalcitonin $(0.21$; reference less than $0.10 \mathrm{ng}$ per $\mathrm{mL}$ ), ferritin (3578; reference range 5-204 ng per $\mathrm{mL}$ ), and normal prothrombin time (14.2 seconds; reference range 12.1-14.8). On hospital day 2, she developed sudden weakness in the left limbs, sensory neglect, left hemianopsia, and right gaze deviation. The stroke team was mobilized to the quarantine COVID unit. Adhering to the isolation protocol implemented by the institution, a N95 face mask was placed on the patient before leaving the unit and all accompanying personnel used personal protective equipment (PPE) including head and body covers, face masks, goggles, and gloves. The initial NIH Stroke Scale (NIHSS) score was 14, and noncontrast head CT was normal. Alteplase (0.9 mg per $\mathrm{kg}$ ) was initiated in the imaging suite (69 minutes after symptoms recognition). CT angiography showed a thrombus in the right middle cerebral artery and a filling defect in the left carotid bulb (figure, A and B). CT perfusion showed a mismatch between cerebral blood volume and mean transit time in the territory of the right middle cerebral artery (figure, $\mathrm{C}$ and $\mathrm{D}$ ). The decision was made to proceed with mechanical thrombectomy in the interventional radiology suite where standard sterilization procedures were applied. The operating team consisted of 4 persons including 1 interventionalist, 2 supporting radiology technologists, and 1 registered nurse; all used PPE. Mechanical thrombectomy was successfully completed under conscious sedation through a transfemoral approach using the standard catheter aspiration with a retrievable stent in the right middle cerebral artery. A diagnostic left carotid angiogram confirmed the presence of a thrombus in the left carotid bulb that was asymptomatic (figure, G). Resolution of the neurologic symptoms

\section{MORE ONLINE}

\section{COVID-19 Resources}

For the latest articles, invited commentaries, and blogs from physicians around the world

NPub.org/COVID19 


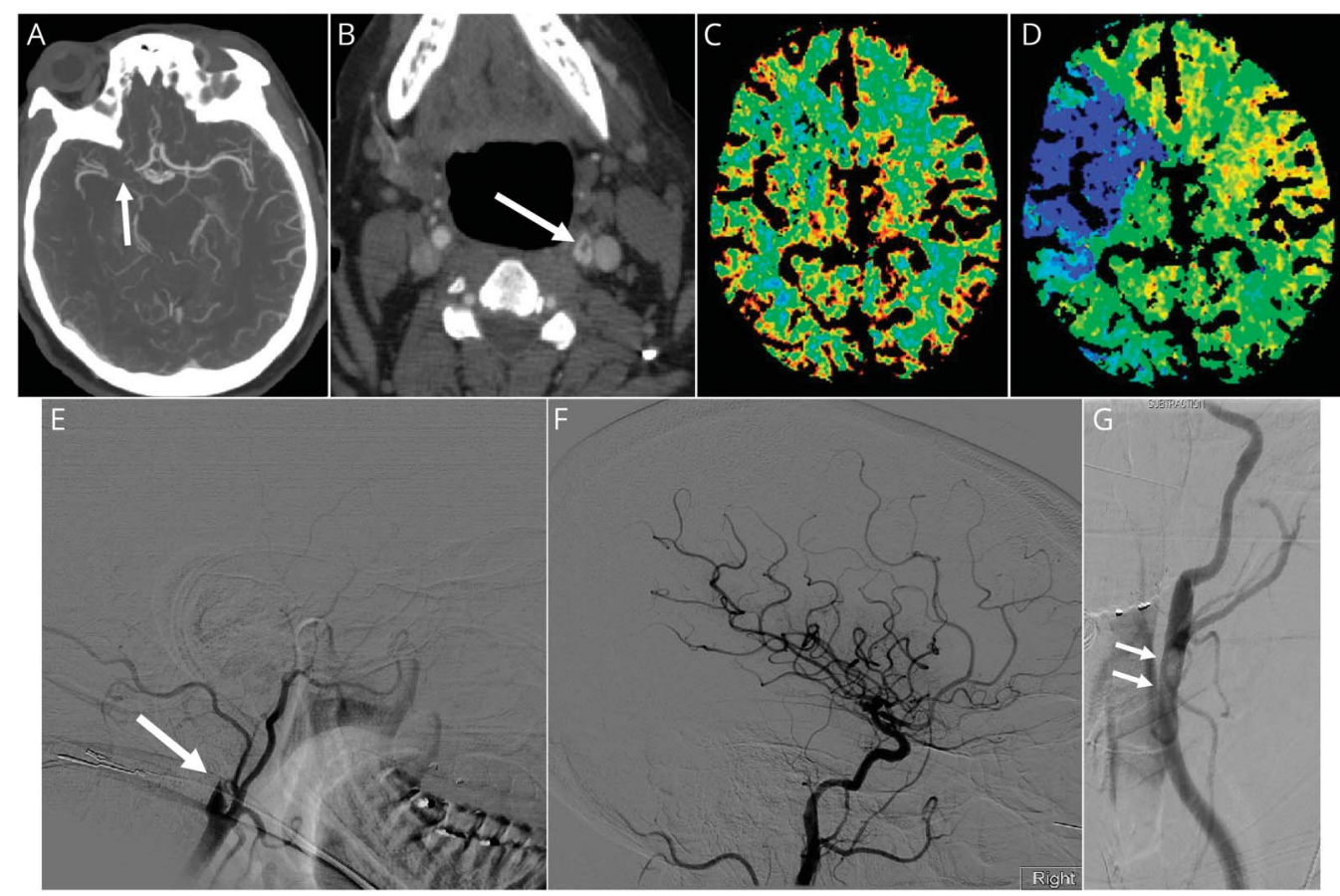

CT angiography showing thrombus and occlusion of the right middle cerebral artery (A) and filling defect in the left carotid bulb (B) suggesting a floating thrombus. CT perfusion showing a mismatch between cerebral blood volume (C) and mean transit time (D) suggesting ischemic penumbra in the territory of the right middle cerebral artery. Conventional angiography of the right common carotid artery (E) showing complete occlusion in the right internal carotid artery followed by complete reperfusion (F) after mechanical thrombectomy. Left carotid angiogram (G) confirms a large floating thrombus in the left carotid bulb.

(NIHSS 5) was immediately noticed after (TICI 3: Thrombolysis In Cerebral Infarction) revascularization of the right middle cerebral artery was achieved (figure, $\mathrm{E}$ and $\mathrm{F}$ ). The patient returned to the quarantine unit where postintervention neurologic monitoring and physical assessment were performed. On postoperative day 2 , the NIHSS dropped to 0 , and a postintervention noncontrast head CT remained normal. Cardiac evaluation including telemetry monitoring and transthoracic echocardiography were normal. Owing to the asymptomatic thrombus in the left carotid system, a 6-month course of oral anticoagulation (apixaban) was commenced. She was discharged to home on hospital day 5 after complete resolution of the respiratory and neurologic symptoms.

\section{Discussion}

Coagulopathy and endothelial dysfunction had been proposed in association with COVID-19; however, the exact mechanism is not yet understood. Our patient had several vascular risk factors, and she may have had an underlying clotting disorder. The COVID-19 infection may have triggered the clotting cascade, resulting in thromboembolism in the bilateral carotid arteries. Based on pathologic and laboratory studies, dynamic hypercoagulation as evidenced by microthrombi throughout the blood vessels of multiple organs may be a sequelae of COVID-19 infection. ${ }^{3}$ Three patients with COVID-19 who developed acute respiratory distress syndrome were treated with intravenous alteplase, targeting the microthrombi in the pulmonary microvasculature. ${ }^{4}$ Our patient had alteplase started on 69 minutes after the recognition of the stroke symptoms, which is delayed compared with our institutional average of 53 minutes. This delay is attributable to the extra precautions applied throughout the management process. We did not believe that alteplase alone would be sufficient in our patient, given the extensive thrombosis in the bilateral carotid arteries. Therefore, mechanical thrombectomy was contemplated despite the risk of spreading the illness to the managing team. Reports from Italy suggested that up to $20 \%$ of healthcare professionals dealing with positive patients became infected with the virus, in some cases resulting in death. ${ }^{5}$ A task force at Stanford University proposed an institutional algorithm based on the patients' risk profile and the urgency of the needed procedure outside the quarantine unit. ${ }^{6}$ Whether to proceed with invasive revascularization procedures in patients with severe COVID-19 infections requiring mechanical ventilation remains an open question. The clinical outcomes in this population have been consistently poor in reported series, even when the patients were functional at baseline. ${ }^{7}$

In extraordinary times, the vigor of reacting to evolving timecritical stroke symptoms must be weighed against the risk of transmitting the virus to healthcare professionals. This case demonstrates the feasibility of interventional stroke management in patients who are COVID-19 positive. However, these aggressive treatment options may need to be limited to patients with viable outcomes, perhaps younger population with fewer 
comorbidities, and patients without respiratory failure requiring mechanical ventilation. Further studies and guidelines are needed in patients who are COVID-19 positive with acute stroke because of large vessel occlusion.

\section{Study Funding}

No targeted funding reported.

\section{Disclosure}

K. Yeboah, R. Edgell, J. Conway and A. Alshekhlee report no disclosures. Full disclosure form information provided by the authors is available with the full text of this article at Neurology.org/cp.

\section{Publication History}

Received by Neurology: Clinical Practice April 16, 2020. Accepted in final form May 18, 2020.

\section{Appendix Authors}

\begin{tabular}{lll}
\hline Name & Location & Contribution \\
\hline $\begin{array}{l}\text { Kevin } \\
\text { Yeboah, MD }\end{array}$ & $\begin{array}{l}\text { St. Louis University, St. } \\
\text { Louis, MO }\end{array}$ & $\begin{array}{l}\text { Analyzed the data, and } \\
\text { drafted the manuscript for } \\
\text { intellectual content }\end{array}$ \\
\hline
\end{tabular}

Appendix (continued)

\begin{tabular}{lll}
\hline Name & Location & Contribution \\
\hline $\begin{array}{l}\text { Randal } \\
\text { Edgell, MD }\end{array}$ & $\begin{array}{l}\text { St. Louis University, St. } \\
\text { Louis, MO }\end{array}$ & $\begin{array}{l}\text { Revised the manuscript for } \\
\text { intellectual content }\end{array}$ \\
\hline $\begin{array}{l}\text { Joseph } \\
\text { Conway, BS }\end{array}$ & $\begin{array}{l}\text { St. Louis University, St. } \\
\text { Louis, MO }\end{array}$ & $\begin{array}{l}\text { Analyzed the data and } \\
\text { revised the manuscript for } \\
\text { intellectual content }\end{array}$ \\
$\begin{array}{l}\text { Amer } \\
\text { Alshekhlee, } \\
\text { MD, MSc }\end{array}$ & $\begin{array}{l}\text { SSM Neurosciences } \\
\text { Institute, and St. Louis }\end{array}$ & $\begin{array}{l}\text { Designed and } \\
\text { conceptualized the study, } \\
\text { analyzed the data, and } \\
\text { drafted the manuscript for } \\
\text { intellectual content }\end{array}$ \\
& & Louis, MO
\end{tabular}

\section{References}

1. World Health Organization. Coronavirus disease (COVID-19) pandemic. Available at: who.int/emergencies/diseases/novel-coronavirus-2019. Accessed April 10, 2020.

2. Tang N, Li D, Wang X, Sun Z. Abnormal coagulation parameters are associated with poor prognosis in patients with novel coronavirus pneumonia. J Thromb Haemost 2020;18:844-847.

3. Ji HL, Zhao R, Matalon S, Matthay MA. Elevated plasmin(ogen) as a common risk factor for COVID-19 susceptibility. Physiol Rev 2020;100:1065-1075.

4. Wang J, Hajizadeh N, Moore EE, et al. Tissue plasminogen activator (tPA) treatment for COVID-19 associated acute respiratory distress syndrome (ARDS): a case series. J Thromb Haemost Epub 2020 Apr 9.

5. Remuzzi A, Remuzzi G. COVID-19 and Italy: what next? Lancet 2020;395: $1225-1228$

6. Forrester JD, Nassar AK, Maggio PM, Hawn MT. Precautions for operating room team members during the COVID-19 pandemic. J Am Coll Surg 2020;230:1098-1101.

7. Bhatraju PK, Ghassemieh BJ, Nichols M, et al. Covid-19 in critically ill patients in the Seattle region—case series. N Engl J Med 2020;382:2012-2022. 


\section{Neurology ${ }^{\circ}$ Clinical Practice}

Interventional Stroke Management in a Patient With COVID-19

Kevin Yeboah, Randal Edgell, Joseph Conway, et al.

Neurol Clin Pract 2021;11;e199-e201 Published Online before print May 21, 2020

DOI 10.1212/CPJ.0000000000000884

This information is current as of May 21, 2020

Updated Information \&
Services

References

Subspecialty Collections

Permissions \& Licensing

Reprints including high resolution figures, can be found at:

http://cp.neurology.org/content/11/2/e199.full.html

This article cites 5 articles, 0 of which you can access for free at: http://cp.neurology.org/content/11/2/e199.full.html\#\#ref-list-1

This article, along with others on similar topics, appears in the following collection(s):

All Cerebrovascular disease/Stroke

http://cp.neurology.org//cgi/collection/all_cerebrovascular_disease_str oke

COVID-19

http://cp.neurology.org//cgi/collection/covid_19

Information about reproducing this article in parts (figures,tables) or in its entirety can be found online at:

http://cp.neurology.org/misc/about.xhtml\#permissions

Information about ordering reprints can be found online:

http://cp.neurology.org/misc/addir.xhtml\#reprintsus

Neurol Clin Pract is an official journal of the American Academy of Neurology. Published continuously since 2011, it is now a bimonthly with 6 issues per year. Copyright ( 2020 American Academy of Neurology. All rights reserved. Print ISSN: 2163-0402. Online ISSN: 2163-0933.

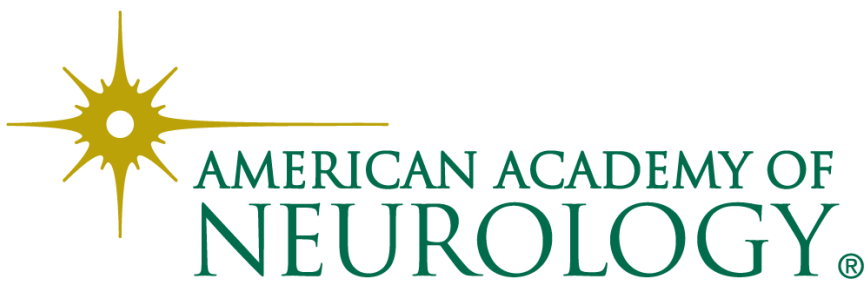

